\title{
Board Structure Problem in Aviation Companies: The Relationship of Political Connection and Multiple Directorship on Firm Performance
}

\author{
Marsya Chikita Lestari ${ }^{*}$, Cynthia Afriani Utama² \\ 1,2Department of Management, Faculty of Economics and Business, University of Indonesia \\ *Corresponding Author: marsya.chikita91@ui.ac.id
}

\begin{abstract}
This study analyzes the relationship between the political connection and multiple directorships of aviation companies' board members and their firm performance. This research will focus on companies in the aviation sector on a broader subsector than previous studies. It will help the shareholder of the aviation companies determine board structure policies and evaluate the implementations conducted so far. This research uses descriptive statistics and regression analysis for the panel data model. Moreover, this study uses a purposive sampling technique secondary data from the aviation company's annual reports in the Asia continent for the 2016-2020 period. The results show that the multiple directorships negatively affect firm performance in aviation companies while the board's political connections positively affect firm performance, measured by its Return on Equity (ROE). In contrast, the multiple directorships and political connections do not impact aviation companies' firm performance measured by their Return on Assets (ROA). Overall, this study in the Asia continent asserts the previous study where the political connection positively affects the airline's firm performance in the US. The result can support the corporate governance practice of deciding board structure in the aviation sectors in Asia in terms of political connection and multiple directorships.
\end{abstract}

Keywords: Aviation Industry; Firm Performance; Multiple Directorships; Political Connection.

\section{INTRODUCTION}

Economic uncertainties have hit the global business several times and imply a high likelihood of adverse economic events. It creates situations where planned spending on consumption and investment is postponed or canceled. However, the size of the impact is different for each business sector. Based on Mckinsey \& Company (2020), the aviation industry got the most significant negative impact among other industries from the most recent disruptions, the Covid-19 Pandemic, with the latest recovery in Q4 2021. Aviation is a vital component of various aspects and contributes significantly to domestic and global economies, national defense, and tourism. However, one of the airline companies, 
failed to achieve the forecasted demand over the last two decades when they invested in the aircraft. Calculating the economic profit (sometimes referred to as economic value add) as the spread between ROCE and WACC, multiplied by capital employed, the airline companies have accumulated an economic loss of $\$ 115$ billion over the past 30 years (Eloff \& Cohen, 2015).

With the lower firm performance, the aviation companies' shareholders want the directors to improve the performance. Therefore, both owners and management in aviation companies imply that governance systems in business activities fit the company's strategies and objectives. In implementing the governance systems, shareholders have a higher interest in choosing directors with well political connections. The political connection may add value to either the connected firms and their managers in many sectors, including aviation companies. With the reclining profit in Garuda Airlines, the shareholder appointed Triawan Munaf, the former head of the Indonesian Creative Economic Agency, as Garuda Airlines's President Commissioner. He is regarded as a vital figure in the creative industry. Currently, Garuda needs business innovation outside its core business. Thus, the airlines' shareholders expected the former government official to increase the firm performance by creating innovation (Rosana, 2020).

A study done by Brogaard \& Detzel (2015) shows that the company can reduce the negative effect of economic turbulence and business uncertainty by having solid political power. These solid political powers can make companies gain the upper hand on the more straightforward implementation and compliance with laws and regulations. However, based on the aviation news in 2020, airlines in China are not reducing their flights and operation cost because the airline's failure will ruin the image of the communist party. Consequently, these decisions impact heavily on the airlines' profitability, especially during the Covid-19 pandemic. Nevertheless, there are mixed results regarding the studies, and the studies cover different industry sectors where studies in aviation industries are still few and mainly covers airline.

Besides considering political connection, aviation's companies' shareholders are also experienced in appointing directors who serve multiple boards when implementing governance. They are positively viewed because they gain the upper hand from their robust knowledge and extensive practice to make a well corporate decision (Manna et al., 2020). Mazzola et al. (2016) also found that a more experienced board, in the form of the network of inter-firm relationships, has a positive relationship with the firm performance measured by new product development. However, despite the advantages of appointing directors who serve on multiple boards, the directors have more jobs and tasks to become swamped and unfocused. Therefore, Harymawan et al. (2019) found that busy directors negatively affect firm performance. This study finding is in line with the phenomenon of the former Garuda Indonesia President Director Ari Askhara's case. Jakarta Post stated that Ari has served as a commissioner in several of Garuda Indonesia's six subsidiaries. However, the firm's financial performance keeps declining over the years, and he got a case on luxury goods embezzlement.

This multiple directorship issue in Indonesia's State-Owned Enterprise (SOE) became one of the main focuses in the Ministry of SOE. According to Minister Erick Thohir in the interview with Jakarta Post, the number of commissioner positions held by the directors indicates the current unhealthy management of SOEs (Wardana, 2019). Based on OJK 33 / POJK Regulation No. 04/2014 Article, committee members may 
concurrently serve up to five committees in a Public Company where they are also members of the Board of Directors or the BOC. Therefore, this phenomenon told that multiple directorships in Garuda Indonesia's case led to performance decrease and regulation in compliance.

Other phenomena regarding multiple directorships also happened in other countries. After the terrible plane crashes of Lion Air Flight 610 and Ethiopian Airlines Flight 302, Boeing, one of the biggest aircraft manufacturers, has been the subject of a law enforcement investigation lawsuit that affected its financial performance. Outside the general public, shareholders and corporate governance experts collectively question the board and leadership's effectiveness and transparency (Tangel, 2019). Wallstreet Journal stated that Boeing's board of directors decided to remove CEO Muilenburg from his role as Chairman in October 2019 (Tangel, 2019). They want the CEO to ensure that Boeing's product and service safety strengthens its safety governance and management processes. Based on this phenomenon, directors' business in multiple boards also indicated the weakness in the governance system, which can affect the firm performance.

Despite the solid political connection between board members and the board members' numerous experiences by serving multiple boards, the aviation industry still suffers from low firm performance. Some airport operator companies that enjoyed stable profits in previous years even declared significant losses during this Covid-19 disease outbreak where the board's connection and experience cannot solve the problem. The consideration of political connection and the director's experience for serving multiple boards in aviation companies raises whether these two factors are relevant to aviation companies' firm performance.

Based on the above problems, this research will analyze the relationship between political connection and multiple directorships in aviation companies' board members on aviation companies' firms. Moreover, this research will focus on companies in the aviation sector on a broader subsector than previous studies, like airports and support services companies. Therefore, this research will benefit the current shareholder in the aviation companies as material in determining regulations regarding board structure in aviation companies and evaluating the implementations that have been conducted so far.

The rest of the paper proceeds as follows. Section 2 explores the literature review associated with political connection, corporate governance, multiple directorships, and firm performance. Therefore, we also develop the hypothesis based on more literature and discussion and conceptual framework. Section 3 explains how we research by describing the research's sample, the operating variables, the data collecting method, the research's model, and the chosen research analysis. We present the result of the research in section 4 and continue the discussion about the research's findings with the existing literature in section 5. Finally, we provide the research's conclusion in section 6, and we also explain the research's limitations and the suggestion for potential researches in the future.

\section{LITERATURE REVIEW AND HYPOTHESES DEVELOPMENT}

\section{Political connection}

Political connections in business are informal relations between companies and government officials. Political connections in business are informal relations between companies and government officials or politicians and are carried out in various ways. A 
firm is politically connected if at least one board member is a current or former minister, parliament, government official, or other politicians (Arifin et al., 2020). The political connection influences corporate financial reporting and performance with four impacts (Preuss \& Königsgruber, 2021). The first impact is that the firm got leveled access to the financial resource by getting into government procurement successfully and receiving debt finance with the procurement contracts-connected firms' enhanced access to financial resources. Politically connected firms are more likely to obtain government procurement contracts and have better access to debt finance. Second, the companies who closely connect to any politician usually will be asked for incentives for the politician's gain. The third impact is that the company usually enjoys the benefit of the changed regulation or low level of enforcement regulation by having a strong connection to politicians. Moreover, the last impact is the company will have more public and media scrutiny when the companies are exposed having these said connection. Therefore, the company will incur additional cost to maintain their transparency and good image. However, more public scrutiny could provoke the companies to provide less disclosures to the public and media.

A study by Wati (2017) stated that political connection theory is related to how politicians or government leaders build relationships with companies to achieve a government agenda that benefits politicians or government supporters. For their political contribution and vote, companies with political connections benefit from contracts or subsidies. Profits that flow from political connections render companies with inefficient political networks and build an inefficiency because of their "protected" status by the government. Political relationships built by other connections are often short-term, unstable, and unclear. It is effortless for managers with a public political identity to participate in the interactions between their companies and the government because they belong to a level of political relations that is more entrenched than ever. Simultaneously, although the manager has influence, the company's actual controller is the board's chairman. Hence, the political connections of the chairman of the board are more important than managers.

\section{Corporate governance and multiple directorships}

Corporate governance refers to how to manage the company and the objectives of that governance. Corporate governance also identifies the owners of power and accountability as well as decision-makers. Corporate governance is a tool that helps companies manage the company and face the challenges and problems that arise within the company (The Chartered Governance Institute, 2020). The board structure is an inseparable part of the corporate governance mechanism. Many studies from ancient times prove that board structure has a significant influence on the company's growth. Organizational frameworks categorize board structures into two types. A one-level council system consists of only one board and is commonly implemented in Anglo-Saxon countries such as the UK, USA, Canada, and India. The two-tier board system has two separate boards, a supervisory board, a management board, and is commonly implemented in Germany, Finland, and the Netherlands.

In various studies and reports, the single-tier board system was favored by board members over the two-tier board system. According to the King Committee on Corporate Governance (2016), board members coordinate better with a single-tier board system dealing with corporate issues than a two-tier board system. They can formulate strategies and conduct performance evaluations as well as build better communication with 
stakeholders. It also shows that a one-board system can build a spirit of cooperation and mutual respect among fellow board members. These two things are required by nonexecutive directors on a one-tier board system so that the public can recognize their contributions to promoting openness and trust. Although the two-tier board system has a less high level of communication than the one-tier board system, implementing a two-tier board system prevents scandals and corruption cases more than the one-tier board system. The two-tier board system has a clear separation between the supervisory function on the one hand and the managerial function on the other. While the one-tier board system combines the two functions, there is still a separation of roles and functions for each director.

The effect of multi directorships can be seen from two perspectives (Saleh et al., 2020). The first perspective, the quality perspective, views many directors as a proxy for high director quality. Directors who serve multiple directors and more networks are expected to generate benefits by bringing in needed resources, suppliers, and customers. Meanwhile, the second perspective, namely the busyness perspective, assumes that directors serving on multiple boards become so busy that they cannot adequately monitor management, which results in high agency costs. In this perspective, busy directors use stewardship theory because stewardship theory assumes a strong relationship between a successful organization and its profitability so that its utility function will be maximized. Judging from this stewardship theory, the board of directors or directors is busy providing benefits for the company. The board of directors is said to have a sound understanding and knowledge of the operations and environment of the company. Meanwhile, the second perspective, namely the busyness perspective, assumes that directors serving on multiple boards become so busy that they cannot adequately monitor management, which results in high agency costs. Because of this, directors serving on multiple boards will be over-committed, and as a result, they tend to neglect their responsibilities.

\section{Firm performance}

Every organization/company, both private and government-owned, has a goal that must be achieved. Within the organization/company, some leaders or managers are in charge of making strategic decisions that can be implemented to achieve these goals. The performance of an organization or company depends on the ability to achieve these goals. The performance evaluation of an organization or company by various parties has different points of view. Most companies try to improve their performance in various ways. Therefore, organizational performance evaluation has always been the main focus for company management and researchers interested in performance assessment (Adetunji \& Owolabi, 2016). Many research often uses firm performance as the dependent variable since it becomes related to strategic management research. The main performance measures of companies usually use financial performance measures such as earnings per share (EPS), return on assets (ROA), return on equity (ROE), and return on sales (ROS) (Taouab \& Issor, 2019). This measure is used in general in various companies to provide information about the company's financial performance that is useful for decision-making in improving the company's performance.

\section{Hypothesis development}

Hypotheses need to be developed in this research to obtain empirical evidence of whether political connections and multiple directorships in aviation companies correlate with the firm's performance in aviation companies. The following is an explanation 
regarding the hypothesis used. There are already many studies about the relationship between political connection with firm performance within different industries. For example, Wang et al. (2018) found that the political connection gains positive views among investors as government endorsement and support signal. Moreover, the firms also successfully get advantages in financial and business aspects and increase their governance system. A recent study by Arifin et al. (2020) found that the practice made the firms get a relatively lower cost of debt. In addition, the firms gain the upper hand from a transactional relationship with politicians since they will give the firm an updated connection with the government in power. Study about political connection in governance system is mainly conducted in China and Hongkong since the communist party has a significant influence over the business. W.-Y. Wong \& Hooy (2018) showed that the board's connection in government's linked company displays a positive relationship with firm performance in China. In the aviation sector, few studies raise the issues of political connection and firm performance. Brown (2016) found that the lobbying intensity and political connections are positively related to the profitability ratio in airlines and their supporting companies in the United States.

Based on the following explanations, the first hypothesis is developed,

\section{$H_{1}$. There is a positive relationship between board members' political connection and firm performance in aviation companies.}

Furthermore, some studies about the relationship between multiple directorships a firm performance are already performed within different industries. In India, Hundal (2017) found that the foreign and government-owned firms in some sectors remain positive in their firm performance. Manna et al. (2020) showed a significant positive relationship between board size and multiple directorships with firm performance through the board's effective decision-making capabilities. A recent study by Chee and Tham (2021) found that the multiple directorships in listed companies in Singapore have a significant positive relationship with firm size and firm performance measured by the company's profitability.

Based on the explanation above, the following hypothesis is developed,

\section{$\mathbf{H}_{2}$. There is a positive relationship between multiple directorships and firm performance in aviation companies.}

Following the hypothesis development, we also find in some studies that some variable also has significant relationship such as leverage, firm size, and firm growth that can be used as control variables in this research. Some previous studies showed a significant positive relationship between the size and profitability of the firm. Aydın Unal et al. (2017) found that large companies are more likely to have a more significant profitability ratio than small companies. Moreover, in a recent study by Subramaniam \& Wasiuzzaman (2019), the firm size is related to Return of Assets (ROA). For leverage, Terjesen et al. (2016) showed that firms with a significant proportion of debt have a negative relationship with their firm performance. However, Ibhagui \& Olokoyo (2018) found that small firms negatively affect leverage and firm performance while large firms positively affect leverage and firm performance. Seissian et al. (2018) also stated the leverage has a significant and positive impact on a firm's profitability, which is listed in NYSE. Many kinds of research analyze the relationship between firm growth and firm performance, resulting in various conclusions. Lee (2018) found that firm growth has a negative and significant effect on the firm's profitability, especially after the economic 
uncertainties. Meanwhile, Subramaniam \& Wasiuzzaman (2019) also stated that firm growth as the control variable positively relates to firm performance in large companies. Therefore, the relationship between variables determining the relationship between political connection and multiple directorships on firm performance in aviation companies can be theoretically illustrated in the following,

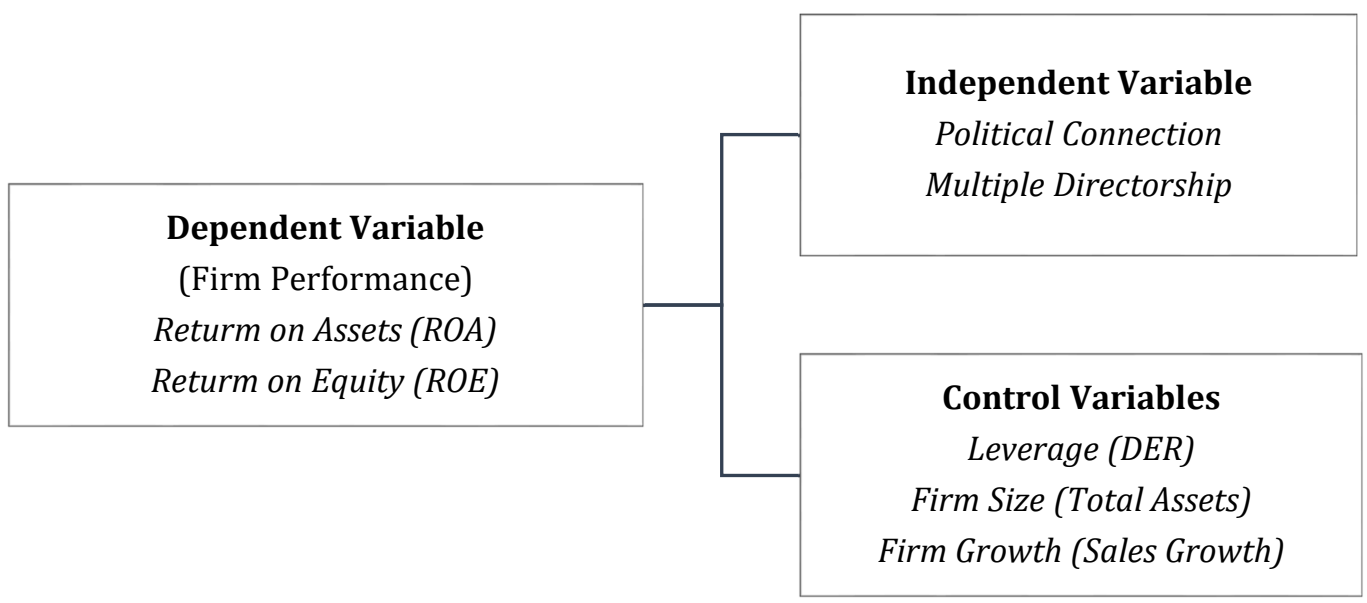

Figure 1. Conceptual Framework

\section{METHOD, DATA, AND ANALYSIS}

Aviation is all activities that are related to mechanical aviation and the aircraft industry. Civil aviation is one of the two main aviation categories representing nonmilitary flights (Air Transport Action Group, 2021). Therefore, civil aviation consists of scheduled / commercial aviation and general aviation. Scheduled aviation is the aviation activities related to all passenger and cargo flights operating on regularly scheduled routes. Meanwhile, general aviation got a broader definition where it includes scheduled and non-scheduled routes

Commercial aviation provides the only fast transportation network worldwide, which makes it essential for global business. It generates economic growth, creates jobs, and facilitates international trade and tourism (Air Transport Action Group, 2021). The aviation industry also provides 62.7 direct and non-direct million jobs across the countries. Airlines, air navigation service providers, and airports directly provide three million jobs, and the manufacture of aircraft, systems, and engines provides one million jobs. Additionally, airports also provide five million jobs across countries. The aviation industry also supports fifty million indirect jobs related to tourism.

Based on the explanation above, aviation companies are the object of this research because their existence is considered necessary. According to Air Transport Action Group (2021), the aviation companies' total economic impact reached 3.5\% of the world's gross domestic product (GDP) in 2014. There are more than 5000 commercial airlines and 17,768 commercial airports in the world with the ICAO code. Therefore, the population in this study is aviation companies in the Asia continent. This study uses one continent since the samples will have the exact geographical location and potentially the same corporate governance mechanism. The sampling technique used is the purposive sampling 
technique, where research is conducted on samples/targets with specific criteria. The criteria for determining this research sample include airlines, airport operators, and supporting companies that publish their reports on their websites from 2016 to 2020. Based on the purposive sampling results, a sample of 51 aviation companies with balanced panel data is listed in Table 1.

Table 1. The Sample Information List

\begin{tabular}{|c|c|c|c|c|c|}
\hline NO & COMPANIES & $\begin{array}{c}\text { STOCK } \\
\text { EXCHANGE AND } \\
\text { COUNTRY }\end{array}$ & NO & COMPANIES & $\begin{array}{c}\text { STOCK } \\
\text { EXCHANGE AND } \\
\text { COUNTRY }\end{array}$ \\
\hline 1 & $\begin{array}{l}\text { PT Garuda } \\
\text { Indonesia }\end{array}$ & $\begin{array}{l}\text { Indonesia } \\
\text { (IDX) }\end{array}$ & 26 & GVK Industries Ltd & $\begin{array}{l}\text { India } \\
\text { (NSE) }\end{array}$ \\
\hline 2 & $\begin{array}{l}\text { All Nippon } \\
\text { Airways }\end{array}$ & $\begin{array}{l}\text { Japan } \\
\text { (TYO) }\end{array}$ & 27 & Hainan Airport Ltd & $\begin{array}{l}\text { China } \\
\text { (SSE) }\end{array}$ \\
\hline 3 & Air China Ltd & $\begin{array}{l}\text { China } \\
\text { (SSE) }\end{array}$ & 28 & $\begin{array}{c}\text { Shanghai Airport } \\
\text { Ltd }\end{array}$ & $\begin{array}{l}\text { China } \\
\text { (SSE) }\end{array}$ \\
\hline 4 & $\begin{array}{l}\text { PT Citilink } \\
\text { Indonesia }\end{array}$ & Indonesia & 29 & $\begin{array}{c}\text { Japan Airport } \\
\text { Terminal }\end{array}$ & $\begin{array}{l}\text { Japan } \\
(\mathrm{TYO})\end{array}$ \\
\hline 5 & China Southern Ltd & $\begin{array}{l}\text { China } \\
\text { (SSE) }\end{array}$ & 30 & Xiamen Airport Ltd & $\begin{array}{l}\text { China } \\
\text { (SSE) }\end{array}$ \\
\hline 6 & China Eastern Ltd & $\begin{array}{l}\text { China } \\
\text { (SSE) }\end{array}$ & 31 & Shenzhen Airport & $\begin{array}{l}\text { China } \\
\text { (SSE) }\end{array}$ \\
\hline 7 & Korean Air Co Ltd & $\begin{array}{l}\text { South Korea } \\
(\mathrm{KRX})\end{array}$ & 32 & Guangzhou Airport & $\begin{array}{l}\text { China } \\
\text { (SSE) }\end{array}$ \\
\hline 8 & Asiana Airlines Inc & $\begin{array}{l}\text { South Korea } \\
\qquad(\mathrm{KRX})\end{array}$ & 33 & $\begin{array}{c}\text { Changi Aiport } \\
\text { Group }\end{array}$ & Singapore \\
\hline 9 & Air Busan Ltd & $\begin{array}{l}\text { South Korea } \\
\qquad(\mathrm{KRX})\end{array}$ & 34 & PT Angkasa Pura I & Indonesia \\
\hline 10 & Jin Air Ltd & $\begin{array}{l}\text { South Korea } \\
\qquad(\mathrm{KRX})\end{array}$ & 35 & PT Angkasa Pura II & Indonesia \\
\hline 11 & Jeju Air Ltd & $\begin{array}{l}\text { South Korea } \\
\text { (KRX) }\end{array}$ & 36 & Incheon Airport Co & $\begin{array}{l}\text { South Korea } \\
(\mathrm{KRX})\end{array}$ \\
\hline 12 & China Airlines Co & $\begin{array}{l}\text { Taiwan } \\
\text { (TWSE) }\end{array}$ & 37 & $\begin{array}{l}\text { Korea Airport } \\
\text { Service }\end{array}$ & $\begin{array}{l}\text { South Korea } \\
(\mathrm{KRX})\end{array}$ \\
\hline 13 & Eva Airways Co & $\begin{array}{l}\text { Taiwan } \\
\text { (TWSE) }\end{array}$ & 38 & Airport of Thailand & $\begin{array}{l}\text { Thailand } \\
\text { (SET) }\end{array}$ \\
\hline 14 & Japan Airlines Co & $\begin{array}{l}\text { Japan } \\
(\mathrm{TYO})\end{array}$ & 39 & $\begin{array}{l}\text { Beijing Capital } \\
\text { Airports }\end{array}$ & $\begin{array}{l}\text { China } \\
\text { (SSE) }\end{array}$ \\
\hline 15 & Hainan Airlines Ltd & $\begin{array}{l}\text { China } \\
\text { (SSE) }\end{array}$ & 40 & $\begin{array}{l}\text { Malaysia Airports } \\
\text { Holdings Berhad }\end{array}$ & $\begin{array}{l}\text { Malaysia } \\
\text { (KLSE) }\end{array}$ \\
\hline 16 & Spice Jet Co & $\begin{array}{l}\text { Thailand } \\
\text { (SET) }\end{array}$ & 41 & SATS & $\begin{array}{l}\text { Singapore } \\
\text { (SGX) }\end{array}$ \\
\hline 17 & Nok Airlines Ltd & $\begin{array}{l}\text { China } \\
\text { (SSE) }\end{array}$ & 42 & $\begin{array}{c}\text { Brahim's Holdings } \\
\text { Berhad }\end{array}$ & $\begin{array}{l}\text { Malaysia } \\
\text { (KLSE) }\end{array}$ \\
\hline 18 & Thai Airways Ltd & $\begin{array}{l}\text { Thailand } \\
\text { (SET) }\end{array}$ & 43 & $\begin{array}{c}\text { PT Cardig Aero } \\
\text { Service }\end{array}$ & $\begin{array}{l}\text { Indonesia } \\
\text { (IDX) }\end{array}$ \\
\hline 19 & Bangkok Airways & $\begin{array}{l}\text { Thailand } \\
\text { (SET) }\end{array}$ & 44 & PT Gapura Angkasa & Indonesia \\
\hline 20 & Cathay Airlines & $\begin{array}{l}\text { Hongkong } \\
\text { (HSE) }\end{array}$ & 45 & $\begin{array}{c}\text { PT Angkasa Pura } \\
\text { Kargo }\end{array}$ & Indonesia \\
\hline 21 & $\begin{array}{c}\text { Airasia Group } \\
\text { BHD }\end{array}$ & $\begin{array}{l}\text { Malaysia } \\
\text { (KLSE) }\end{array}$ & 46 & $\begin{array}{c}\text { PT Angkasa Pura } \\
\text { Solusi }\end{array}$ & Indonesia \\
\hline
\end{tabular}




\begin{tabular}{|c|c|c|c|c|c|}
\hline NO & COMPANIES & $\begin{array}{c}\text { STOCK } \\
\text { EXCHANGE AND } \\
\text { COUNTRY }\end{array}$ & NO & COMPANIES & $\begin{array}{c}\text { STOCK } \\
\text { EXCHANGE AND } \\
\text { COUNTRY }\end{array}$ \\
\hline 22 & Singapore Airlines & $\begin{array}{l}\text { Singapore } \\
\text { (SGX) }\end{array}$ & 47 & $\begin{array}{l}\text { PT Angkasa Pura } \\
\text { Propertindo }\end{array}$ & Indonesia \\
\hline 23 & Cebu Air & $\begin{array}{l}\text { Philippines } \\
\text { (PSE) }\end{array}$ & 48 & Air Asia Co Ltd & $\begin{array}{l}\text { Taiwan } \\
\text { (TWSE) }\end{array}$ \\
\hline 24 & Emirates Airlines & Dubai & 49 & $\begin{array}{c}\text { PT Garuda } \\
\text { Maintenance Facility }\end{array}$ & $\begin{array}{l}\text { Indonesia } \\
\text { (IDX) }\end{array}$ \\
\hline \multirow[t]{2}{*}{25} & Qatar Airways & Qatar & 50 & InterGlobe Aviation & $\begin{array}{l}\text { India } \\
\text { (NSE) }\end{array}$ \\
\hline & & & 51 & $\begin{array}{l}\text { TAAL Enterprise } \\
\text { Ltd }\end{array}$ & $\begin{array}{l}\text { India } \\
\text { (NSE) }\end{array}$ \\
\hline
\end{tabular}

This study uses secondary data as the study's source. Secondary data is the data obtained and collected by researchers from various sources such as the internet, books, journals, and previous research. We got financial and board structure and characteristics information from the companies' websites' corporate reports. This research will be conducted on aviation companies that originated from the Asia continent from 2016 until 2020. In this study, the aviation companies will be focused on broader subsectors such as airlines, airport operators, and supporting companies to airports and airlines. The time of the study will be conducted from July 2020 to May 2021.

We developed a statistical model to test the relationship between firm performance with political connections and multiple directorships to test the study's hypothesis. Firstly, we set two dependent variables (Y), ROA and ROE, to represent the firm performance. Ratios measure these two indicators. Return on assets variable will define firm performance related to assets' accounting performance. Return on equity variable will define firm performance related to the equity holder's accounting performance.

1. Return on Assets

Return on assets variable will define firm performance related to assets' accounting performance. We will set the indicator as to the ratio of net income to total assets. The formula for calculating the ROA indicator is, ROA: Net Income / Total Assets * 100\%

2. Return on Equity

Return on equity variable will define firm performance related to the equity holder's accounting performance. We will set the indicator as to the ratio of net income to total assets. The formula for calculating the ROE indicator is,

ROE: Net Income / Total Equity * 100\%

Furthermore, we set two independent variables $(X)$ for this study: political connection and multiple directorships. We set two independent variables for this study: political connection and multiple directorships. Therefore, we developed two indicators, former government officials and commissioners in numerous boards at companies, to represent the board structure and characteristics in corporate governance mechanism. Ratios measure these two indicators. 
1. Political Connection

A firm is politically connected if at least one board member is a current or former minister, parliament, government official, or politician (Arifin et al., 2020). Thus, we use the proportion of politically connected board members by counting the number of the board of commissioner members who have experience as a former minister, government, and military officials dividing it by the total number of boards of commissioner members.

PC $=$ Politically connected board members / Total number of board members .

\section{Multiple Directorship}

We use the proportion of board members with multiple directorships by counting the number of the board of director members who serve as the board of commissioners in other companies and dividing it by the total number of board of directors' members,

MD = Board members with multiple directorships / Total number of board members

This study follows the previous study to determine the variables related to the control variable's firm performance. These variables are related to firm characteristics such as ownership structures, firm size, leverage, and sales growth (Ibhagui \& Olokoyo, 2018; Lee, 2018; Terjesen et al., 2016; Vithessonthi \& Tongurai, 2015). Therefore, we set three control variables, firm size, leverage, and firm growth. These three control variables will have total assets, DER, and sales growth as indicators.

\section{Firm Size}

In empirical corporate finance, firm size is frequently applied as a firm characteristic. We used total assets as the indicator to measure firm size. Generally speaking, total assets measure total firm resources, and it is defined with the natural algorithm of total assets in US dollar currency.

\section{Leverage}

Based on agency theory, leverage can be used to discipline management and positively influence firm performance. We used DER as the indicator to measure the leverage. DER is a ratio to show the company's debt level to the total shareholder's equity as a funding source. The formula for calculating the DER indicator is

DER: Total Debt / Total Equity * $100 \%$

3. Firm's Growth

Sales growth represents an increase in sales generated by a company (Julianto and Jogiyanto, 2002). In this study, the calculation formula sales growth is as follows:

Sales Growth: Total Sales (t) / Total Sales ( $\mathrm{t}-1)$ * $100 \%$

The data analysis in this research is started by identifying and transforming the data to be fitted for analysis. For the sake of multiple directorships and political connections represented by the companies in aviation sectors and their firm performance, this research used panel data analysis. Panel data is a regression that combines time-series data and cross-section data (Pesaran, 2015). There are several advantages to using panel data estimation. The researchers can increase the number of observations (samples) and 
get more data character variation (Pesaran, 2015). According to Daoud (2017), panel data has little collinearity between variables, so there is a tiny possibility of multicollinearity. Based on this description, this study's classical assumptions are normality, multicollinearity, and heteroscedasticity test.

Therefore, we will develop statistical models to test the hypothesis and validate the models. Then, we will use quantitative analysis using descriptive statistics and regression analysis for the data panel. Descriptive statistics summarize and provide a general description and pattern of data regarding the sample's characteristics to be studied. Descriptive statistics will be performed on each indicator of the research variable. Consequently, we will interpret the result of quantitative research to make conclusions and recommendations. According to Rizka (2019), the analysis using panel data is a combination of time series and cross-section, as shown in equation 1 .

$$
Y i=\beta 0+\beta 1 X i+\varepsilon i ; I=1,2 \ldots N
$$

Where $\mathrm{N}$ is the number of cross-section data since panel data is a combination of time-series and cross-section, the model can be written by:

$$
\begin{array}{ll}
\text { Yit } & =\beta 0+\beta 1 X i t+\varepsilon i t \\
\mathrm{I} & =1,2 \ldots \mathrm{N} ; \mathrm{t}=1,2 \ldots \mathrm{T} \\
\mathrm{N} & =\text { the number of observations } \\
\mathrm{T} & =\text { period } \\
\mathrm{N} \times \mathrm{T} & =\text { the number of panel data }
\end{array}
$$

This research concerned the relationship of multiple directorships and political connection with firm performance with the control variable of firm size, firm growth, and leverage, using time-series data for five years which represented annual data from 2016 to 2020, and cross-section data as much as 51 aviation companies in Asia that resulted in 249. observation balanced panel data that can be written as following equation 2 and 3 .

1. ROA Equation Model

$$
\begin{array}{ll}
\qquad \text { ROAit } & =\beta 0+\beta 1 \text { MDit }+\beta 2 \text { PolCONit }+\beta 3 L_{-} N_{\text {FSit }}+\beta 4 \text { FGit }+\beta 4 \text { Lit }+\mu i t \\
\text { Y } & =\text { ROA } \\
\text { M.D. } & =\text { Multiple Directorship } \\
\text { Polcon } & =\text { Politic Connection } \\
\text { F.S. } & =\text { Firm size } \\
\text { F.G. } & =\text { Firm Growth } \\
\text { FS } & =\text { Leverage } \\
\beta 0 & =\text { Intercept }
\end{array}
$$

\section{ROE Equation Model}

$$
\begin{array}{ll}
\text { ROEit }= & \beta 0+\beta 1 \text { MDit }+\beta 2 \text { PolCONit }+\beta 3 L N_{-} F \text { Sit }+\beta 4 \text { FGit }+\beta 4 L i t+\mu i t \\
\text { Y } & =\text { ROE } \\
\text { M.D } & =\text { Multiple Directorship } \\
\text { Polcon } & =\text { Politic Connection }
\end{array}
$$




$$
\begin{array}{ll}
\text { F.S. } & =\text { Firm size } \\
\text { F.G } & =\text { Firm Growth } \\
\text { F.S. } & =\text { Leverage } \\
\beta 0 & =\text { Intercept }
\end{array}
$$

A regression model with panel data generally results in difficulty in model specifications. The residual will have three possibilities: residual time series, cross-section, or both combinations. Two common approaches to estimate a regression model with panel data are the fixed effect model approach and the random effect model approach from three approaches to the panel data method. The Hausman test uses the F test to choose between a random effect or fixed effect to determine the method between pooled least square and fixed effect. The F-test, Chow Test, and Hausman test to estimate the regression models with the panel data. This research will use Stata software to run the analysis (Pillai N., 2016).

In a panel of data processing, this mechanism determines the method for selecting the appropriate panel data by comparing the approach Pooled Least Square method with the Fixed Effect Model approach first. If the results show the Pooled Least Square approach model accepted, then Pooled Least Square approach will be analyzed. If the model Fixed Effect model is accepted, compare it again with Random Effect Model approach. To carry out which model is more suitable to be used, the research will use Chow Test, Lagrange Multiplier Test, and Hausman Test. Moreover, hypothesis testing in this study can be measured from the goodness of fit of the regression function. Statistically, this analysis can be measured from the $t$ statistical value, the $F$ statistical value, and the coefficient of determination (Veazie, 2015). This regression analysis aims to partially or simultaneously determine the effect of the independent variable on the dependent variable and determine the proportion of the independent variable in explaining changes in the dependent variable.

We also use a correlation test to determine the close relationship between two variables and know the relationship's direction. This research uses the Pearson correlation test to test the research's hypothesis (Morrisan, 2019). The correlation coefficient value ranges from -1 to +1 , which has criteria its use is as following Table 2 .

Table 2. Level of Size of Correlation

\begin{tabular}{ll}
\hline Size of Correlation & Interpretation \\
\hline Less than 0.2 & No Correlation \\
\hline $0,20-0,40$ & Low Degree \\
\hline $0,40-0,70$ & Moderate Degree \\
\hline $0,70-0,90$ & High Degree \\
\hline More than 0,90 & Perfect \\
\hline
\end{tabular}

Source : (Morrisan, 2019).

\section{RESULTS}

\section{Descriptive statistical analysis results}

Descriptive statistical analysis was carried out to identify the characteristics of the sample in the study in general. Descriptive statistics include extreme values, namely maximum and minimum values, mean, and standard deviation. These results are then 
analyzed to obtain sample characteristics according to the study's variables. Furthermore, the results of the descriptive statistics for each variable can be seen in Table 3 .

Table 3. Descriptive Statistics Result

\begin{tabular}{ccrrrr}
\hline Indicator & N & \multicolumn{1}{c}{ Min } & Max & \multicolumn{1}{c}{ Mean } & Std. Deviation \\
\hline Sales Growth & 249 & $-83 \%$ & $86 \%$ & $-1 \%$ & $24 \%$ \\
Total Assets & 249 & 9.36 & 17.58 & 14.39 & 2.11 \\
ROA & 249 & $-40 \%$ & $27 \%$ & $2 \%$ & $9 \%$ \\
ROE & 249 & $-268 \%$ & $126 \%$ & $3 \%$ & $34 \%$ \\
DER & 249 & $-2415 \%$ & $4421 \%$ & $189 \%$ & 4.72 \\
Multiple Directorship & 249 & $43 \%$ & $100 \%$ & $88 \%$ & $14 \%$ \\
Former Government Officials & 249 & $11 \%$ & $100 \%$ & $51 \%$ & $26 \%$ \\
\hline
\end{tabular}

Source: Data processed by researchers using Stata, 2021

Based on the descriptive statistics generated from the 249 observations of companies in aviation sectors, the average value of ROA is $2 \%$, and ROE is $3 \%$ in 5 years. Both ratios reflect the company's accounting value or book value, which tends to experience a significant decline due to the Covid-19 pandemic. The ratio will measure the amount of return generated from the company's assets. Thus, ROA is a reflection of a company's efficiency in managing its assets. The ROA indicator shows a minimum value of $-40 \%$, P.T. Garuda Indonesia Tbk's value in 2014. Meanwhile, the maximum value of $27 \%$ is the value of Taal Enterprise in 2017. The average value is $2 \%$, with a standard deviation of $9 \%$.

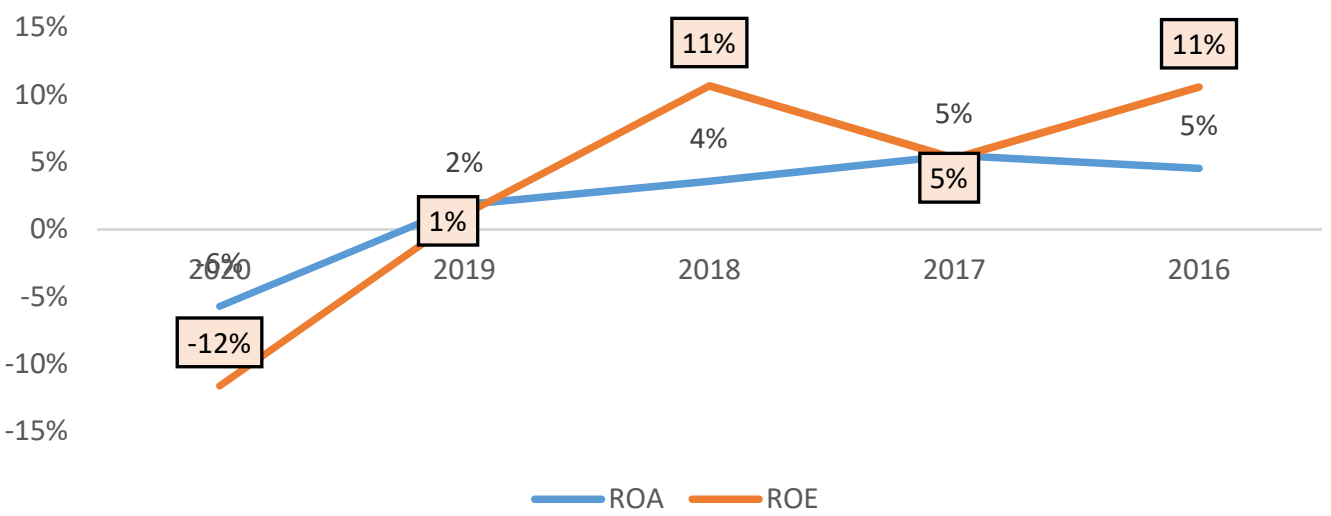

Figure 2. Average Value of Firm Performance

The ROE value measures the amount of return related to the company's equity. The indicator shows a minimum value of $-268 \%$, which is the value of Nok Airlines in 2017. Meanwhile, the maximum value of $126 \%$ is the value of GVK in 2018. The average value is $3 \%$, with a standard deviation of $34 \%$. The ROE value measures the amount of return related to the company's equity. The indicator shows a minimum value of $-268 \%$, which is the value of Nok Airlines in 2017.

Meanwhile, the maximum value of $126 \%$ is the value of GVK in 2018 . The average value is $3 \%$, with a standard deviation of $34 \%$. It means the firm performance is low compared to other industries, although it is typical for aviation industries. 
The independent variables consist of two indicators, namely Multiple Directorship and Political Connection. Multiple directorships are the likenesses of the percentage of total board members who serve multiple boards in other companies. The average percentage value does not have significant fluctuation during five years, even during Covid 19 pandemic. The multiple directorships indicator shows a minimum value of $43 \%$, which is the value of Asiana Airlines in 2019. Meanwhile, the maximum value of $100 \%$ is the value of some companies in multiple years, such as aviation companies from China. The average value is $88 \%$, with a standard deviation of $14 \%$. The result indicates that most of the board of directors in the aviation company serves multiple commissioner boards.

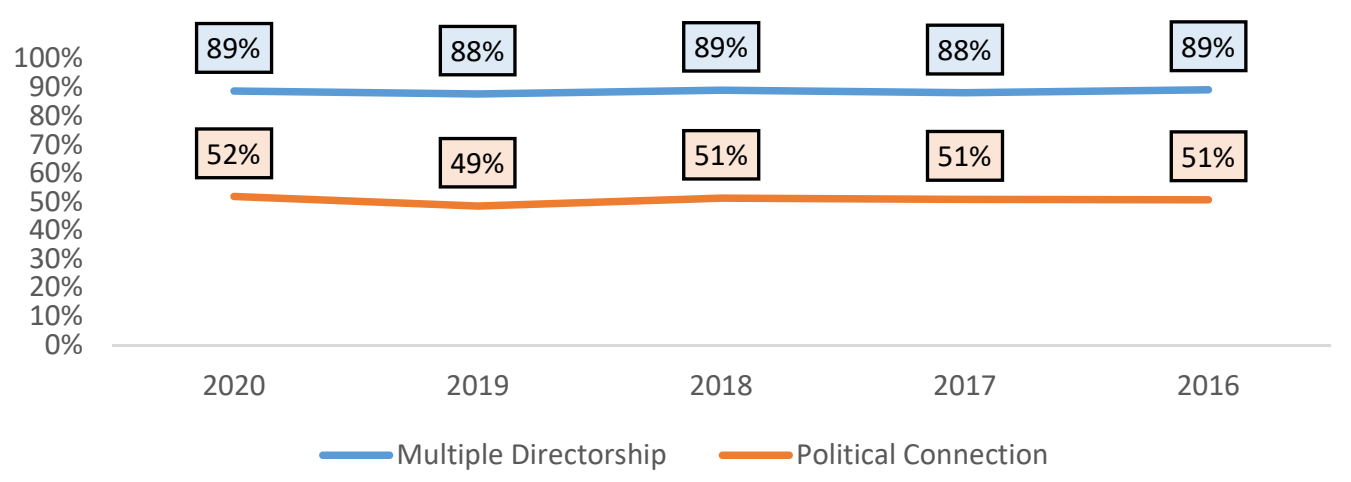

Figure 3. Average Value of Multiple Directorship and Political Connection

Political connections reflect the percentage of total board members who are current or former ministers, members of parliament, government officials, or some other politician. The average percentage value does not have significant fluctuation during five years, even during Covid 19 pandemic. The political connection indicator shows a minimum value of $11 \%$, which is the value of SATS in 2020 . Meanwhile, the maximum value of $100 \%$ is the value of some companies in multiple years, such as aviation companies from China where the board members from the communist party. The average value is $51 \%$, with a standard deviation of $26 \%$. The results mean that half of the board of commissioner board for the aviation companies are former government officials.

The control variables consist of three variables, which are firm growth, firm size, and leverage. Firm growth got the indicator set with sales growth. The sales growth reflects the fluctuation in the number of sales generated by a company. The average value of sales growth for aviation companies decreases significantly during the Covid-19 pandemic. The sales growth indicator shows a minimum value of $-83 \%$, which is the value of Changi Airport Group in 2020. Meanwhile, the maximum value of $86 \%$ is the value of Angkasa Pura Solusi in 2017. The average value is $-1 \%$, with a standard deviation of $24 \%$. 


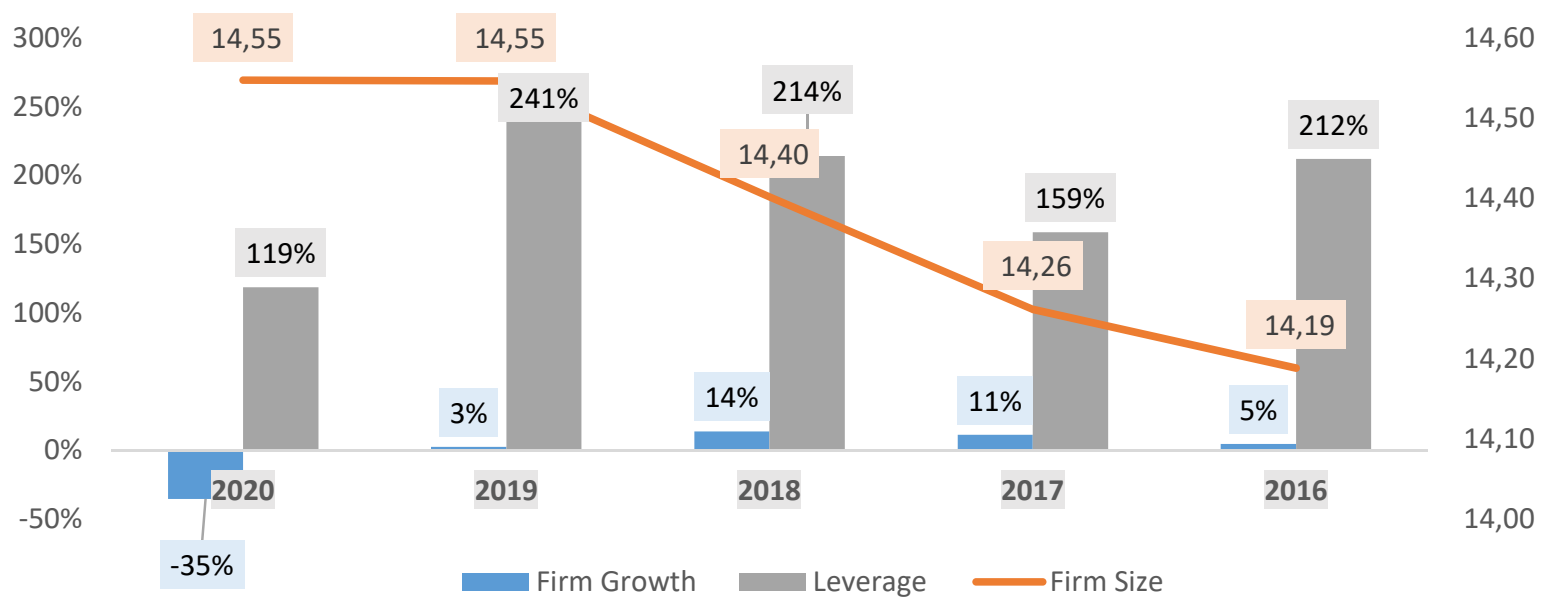

Figure 4. Average Value of Firm Growth, Size, and Leverage

Firm size got the indicator set with total assets with natural logarithm value. The total assets reflect the total shareholder equity and liabilities of the company. The average value of total for aviation companies decreases during the Covid-19 pandemic, although not as much as the sales growth, showing that the company tried to have an efficient operation and got funding. The total assets indicator shows a minimum value of 9.36, which is the value of Spice Jets in 2016. Meanwhile, the maximum value of 17.58 is the value of China Southern Airlines in 2017. The average value is 14.39, with a standard deviation of 2.11 .

Firm leverage got the indicator set with debt-to-equity ratio. The debt-to-equity ratio reflects its debt level to the total shareholder's equity as a funding source. The average value of the debt-to-equity ratio significantly decreases during the Covid-19 pandemic because of the negative equity value in airlines, although total liability increased. The debt-to-equity ratio indicator shows a minimum value of $-2415 \%$, which is the value of Air Asia Airlines in 2020. Meanwhile, the maximum value of $4421 \%$ is the value of PT Angkasa Pura Solusi in 2018. The average value is $189 \%$, with a standard deviation of $472 \%$.

\section{Classical assumption test results}

After the descriptive statistics method, the research carries a classical assumption test to assess whether the research models are sufficient for the best linear unbiased estimator (BLUE) requirements. Based on the classical assumption tests done in panel data, the data has been confirmed to meet the assumptions of normality, heteroscedasticity, and multicollinearity with robust standard error (Alejo et al., 2015; Moscone \& Tosetti, 2015; Pek et al., 2018). Thus, it can be concluded that this research can be continued to the hypothesis testing stage. 
Correlation analysis between variables results

Table 4. Descriptive Statistics Result

\begin{tabular}{|c|c|c|c|c|c|c|c|c|}
\hline & & ROA & ROE & $\begin{array}{c}\text { Multiple } \\
\text { Directorship }\end{array}$ & $\begin{array}{c}\text { Political } \\
\text { Connection }\end{array}$ & $\begin{array}{c}\text { Firm } \\
\text { Growth }\end{array}$ & $\begin{array}{c}\text { Firm } \\
\text { Size }\end{array}$ & Leverage \\
\hline \multirow{3}{*}{$\mathrm{ROA}$} & Pearson & & & & & & 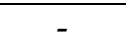 & \\
\hline & Correlation & 1.000 & 0.870 & 0.055 & 0.069 & -0.001 & 0.003 & 0.000 \\
\hline & $\begin{array}{l}\text { Sig. (1- } \\
\text { tailed) }\end{array}$ & & 0.000 & 0.191 & 0.135 & 0.495 & 0.481 & 0.498 \\
\hline \multirow{3}{*}{$\mathrm{ROE}$} & Pearson & & & & & & 0.186 & \\
\hline & Correlation & 0.870 & 1.000 & 0.076 & 0.007 & -0.007 & * & $-0.248^{*}$ \\
\hline & $\begin{array}{l}\text { Sig.(1- } \\
\text { tailed) }\end{array}$ & 0.000 & & 0.113 & 0.453 & 0.458 & 0.001 & 0.000 \\
\hline \multirow{3}{*}{$\begin{array}{l}\text { Multiple } \\
\text { Director } \\
\text { ship }\end{array}$} & Pearson & & & & & & & \\
\hline & Correlation & 0.055 & 0.076 & 1.000 & -0.025 & 0.063 & $-0.246^{*}$ & -0.076 \\
\hline & tailed) & 0.191 & 0.113 & & 0.344 & 0.158 & 0.000 & 0.114 \\
\hline \multirow{3}{*}{$\begin{array}{l}\text { Political } \\
\text { Connecti } \\
\text { on }\end{array}$} & Pearson & & & & & & 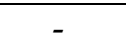 & \\
\hline & Correlation & 0.069 & 0.007 & -0.025 & 1.000 & -0.007 & 0.018 & 0.047 \\
\hline & $\begin{array}{l}\text { Sig.(1- } \\
\text { tailed) }\end{array}$ & 0.135 & 0.453 & 0.344 & & 0.458 & 0.389 & 0.230 \\
\hline \multirow{3}{*}{$\begin{array}{l}\text { Firm } \\
\text { Growth }\end{array}$} & Pearson & - & & & & & - & \\
\hline & Correlation & 0.001 & -0.007 & 0.063 & -0.007 & 1.000 & 0.019 & 0.001 \\
\hline & Sig.(1- & 0405 & 0 & 0158 & 0458 & & 0201 & 05 \\
\hline \multirow{3}{*}{$\begin{array}{l}\text { Firm } \\
\text { Size }\end{array}$} & Pearson & - & & & & & & \\
\hline & Correlation & 0.003 & $0.186^{*}$ & $-0.246^{* *}$ & -0.018 & -0.019 & 1.000 & 0.063 \\
\hline & $\begin{array}{l}\text { Sig.(1- } \\
\text { tailed) }\end{array}$ & 0.481 & 0.001 & 0.000 & 0.389 & 0.381 & & 0.160 \\
\hline \multirow{4}{*}{ Leverage } & & & 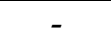 & & & & & \multirow{4}{*}{1.000} \\
\hline & Pearson & & $0.248^{*}$ & & & & & \\
\hline & Correlation & 0.000 & * & -0.076 & 0.047 & 0.001 & 0.063 & \\
\hline & $\begin{array}{l}\text { Sig.(1- } \\
\text { tailed) }\end{array}$ & 0.498 & 0.000 & 0.114 & 0.230 & 0.495 & 0.160 & \\
\hline
\end{tabular}

Source: Data processed by researchers using Stata, 2021

Based on the Pearson Correlation test results in Table 4, firm size is positively correlated with ROE, while leverage is negatively correlated with ROE. Both are significant at the $1 \%$ level. On the other hand, there is no single factor that is correlated with returns. In addition, firm size is negatively correlated with multiple directorships. Thus, it is concluded that $\mathrm{H} 1$ and $\mathrm{H} 2$ are not proven in this analysis.

\section{Determination of panel-data model analysis techniques}

Table 5. Chow Test and Lagrange Multiple Test Result

\begin{tabular}{ccc}
\hline Detail & Chow Test & Lagrange Multiplier Test \\
\cline { 2 - 3 } & $\begin{array}{c}\text { Prob Value } \\
\text { (Cross-Section F) }\end{array}$ & $\begin{array}{c}\text { Prob Value } \\
\text { (Cross-Section } \bar{X}^{2} \text { ) }\end{array}$ \\
\hline ROA & 0.3648 & 0.4121 \\
ROE & 0.1349 & 0.1649 \\
\hline
\end{tabular}

Source: Data processed by researchers using Stata, 2021 
Based on the Chow and Lagrange Multiplier test in Table 5, the probability value in the ROA and ROE model equation for the Chow Test and Lagrange Multiplier Test is more significant than alpha 0.05 . The Chow test proves that the fixed effect is irrelevant for use. The multiple directorships and political connection results using Fixed Effect Model and Random Effect Model are also not significant based on the explanation of the panel-data analysis in the next section. Therefore, it is concluded that the PLS model is the best fit for both ROA and ROE models.

\section{Panel-data analysis}

Table 6. Regression Analysis Result without Control Variables - ROA \& ROE

\begin{tabular}{lcccccc}
\hline $\begin{array}{l}\text { Independent } \\
\text { Variable }\end{array}$ & \multicolumn{3}{c}{ ROA } & & \multicolumn{3}{c}{ ROE } & \\
\cline { 2 - 7 } & PLS & FEM & REM & PLS & FEM & REM \\
\hline $\begin{array}{l}\text { Multiple } \\
\text { Directorship }\end{array}$ & 0.214 & 0.579 & 0.232 & 0.344 & 0.562 & 0.343 \\
$\begin{array}{l}\text { Political } \\
\text { Connection }\end{array}$ & 0.479 & 0.634 & 0.483 & 0.271 & 0.114 & 0.270 \\
Constant & 0.304 & 0.405 & 0.326 & 0.308 & 0.723 & 0.370 \\
Sig F / 2 2 & 0.3510 & 0.6543 & 0.3751 & 0.3574 & 0.2857 & 0.3559 \\
\hline
\end{tabular}

Source: Data processed by researchers using Stata, 2021

Based on the analysis result in table 6 for the ROA and ROE model equation without the control variables in PLS, we can see the F test resulted in a probability of 0.3510 for ROA and 0.3574 for ROE, a significance level of 0.05 . The F test with the FEM model resulted in a probability of 0.6543 for ROA and 0.2857 for ROE with a significance level of 0.05 . Moreover, the $\chi 2$ test with the REM model resulted in a probability of 0.3751 and 0.3559 with a significance level of 0.05 . Thus, the model without the control variable is not fit to predict the firm performance as proxied by ROA and ROE in PLS, FEM, and REM. The t-test and z-test results show that the values for the variable of multiple directorships and political connections are higher than the significance level of 0.05 for the three models. Thus, these independent variables do not significantly affect ROA and ROE in the three models.

Table 7. Pooled Least Square Regression Analysis Result - ROA

\begin{tabular}{ccccc}
\hline Independent Variable & $\boldsymbol{\beta}$ & $\begin{array}{c}\text { Standard } \\
\text { Error }\end{array}$ & t-count & Sig. t \\
\hline Multiple Directorship & -6.224072 & 10.62062 & -0.59 & 0.558 \\
Political Connection & 6.015224 & 5.296622 & 1.14 & 0.256 \\
Firm Growth & 0.0195593 & 0.0579158 & 0.34 & 0.736 \\
Firm Size & $-5.5 \mathrm{E}-08$ & $2.69 \mathrm{e}-08$ & 2.06 & 0.040 \\
Leverage & 1.131607 & 1.017714 & -1.11 & 0.267 \\
Constant & 3.881939 & 8.559937 & 0.45 & 0.651 \\
\hline R-squared & 0.747 & & & \\
F-count & 7.98 & & & \\
Sig F & 0.0000 & & &
\end{tabular}

Source: Data processed by researchers using Stata, 2021

Based on the regression analysis result for the ROA model equation in table 7 , the $\mathrm{F}$ test resulted in a probability of 0.0000 with a significance level of 0.05 . Thus, the model with the control variable is fit to predict the firm performance as proxied by ROA. However, the t-test results show that the values for the variable of multiple directorships, 
political connection, firm growth, and leverage are higher than the significance level of 0.05. These independent variables do not significantly affect ROA, while firm size negatively affects ROA.

Table 8. Pooled Least Square Regression Analysis Result - ROE

\begin{tabular}{lrrrr}
\hline Independent Variable & $\boldsymbol{\beta}$ & $\begin{array}{c}\text { Standard } \\
\text { Error }\end{array}$ & t-count & Sig. t \\
\hline Multiple Directorship & -1.874271 & 0.6895102 & -2.72 & 0.007 \\
Political Connection & 0.8062486 & 0.3967399 & 2.03 & 0.043 \\
Firm Growth & 0.0077752 & 0.0052336 & 1.49 & 0.139 \\
Firm Size & $-1.28 \mathrm{E}-08$ & $3.77 \mathrm{E}-09$ & -3.4 & 0.001 \\
Leverage & 0.5082524 & 0.1360083 & 3.74 & 0.000 \\
Constant & 1.2061 & 0.5577762 & 2.16 & 0.032 \\
\hline R-squared & 0.7657 & & & \\
F-count & 3.40 & & & \\
Sig F & 0.0054 & & & \\
\hline So
\end{tabular}

Source: Data processed by researchers using Stata, 2021

For the ROE model equation in table 8 , the $\mathrm{F}$ test resulted in a probability of 0.0054 with a significance level of 0.05 . Thus, the model with the control variable is fit to predict the firm performance as proxied by ROE. Furthermore, the t-test results show that the values for the variables of political connection, multiple directorships, firm size, and leverage are less than the significance level of 0.05 . Thus, these independent variables have a significant effect on ROE. However, the multiple directorship's coefficient values are negative, which means the multiple directorships negatively influence firm performance. Meanwhile, the political connection's coefficient value is positive, which means political connection positively influences the firm performance. For the control variable, leverage has a significant positive relationship, and firm size has a significant negative relationship with ROE.

Table 9. Fixed Effect (FEM) and Random Effect (REM) Regression Analysis Result - ROA

\begin{tabular}{lrrrrrr}
\hline \multirow{2}{*}{ Independent Variable } & \multicolumn{3}{c}{ FEM } & \multicolumn{3}{c}{ REM } \\
\cline { 2 - 7 } & \multicolumn{1}{c}{$\boldsymbol{\beta}$} & $\mathbf{t}$-count & Sig. $\mathbf{t}$ & $\boldsymbol{\beta}$ & Z-count & Sig. Z \\
\hline Multiple Directorship & 35.1189 & 0.78 & 0.439 & -5.478851 & -0.39 & 0.700 \\
Political Connection & -1.558353 & -0.04 & 0.971 & 6.108965 & 0.80 & 0.426 \\
Firm Growth & 0.0296452 & 0.07 & 0.944 & 0.0184753 & 0.05 & 0.961 \\
Firm Size & $7.27 \mathrm{e}-08$ & 1.59 & 0.114 & $5.71 \mathrm{e}-08$ & 1.63 & 0.102 \\
Leverage & -1.174661 & -3.87 & 0.000 & -1.13694 & -4.19 & 0.000 \\
Constant & -29.03372 & -0.77 & 0.443 & 3.178145 & -0.77 & 0.814 \\
\hline & R-squared & 0.00425 & & R-squared & 0.0747 & \\
& F-count & 3.29 & & F-count & 20.02 & \\
& Sig F & 0.0071 & & Sig X 2 & 0.0012 & \\
\hline
\end{tabular}

Source: Data processed by researchers using Stata, 2021

Still, the data used in this study is panel data, and regression analysis using Pooled Least Square (PLS) cannot see the difference between individuals and the difference between times. PLS assumes that the intercept and slope of the model have the same characteristic. Therefore, this research carried out the Fixed Effects Model (FEM) and Random Effects Model (REM) to accommodate the weaknesses of the regression analysis using PLS. Based on Table 9, the F test with REM and FEM model resulted in a probability of 0.0071 and 0.0012 with a significance level of 0.05 . Thus, both models that 
use the control variable are fit to predict the firm performance as proxied by ROA. Furthermore, the t-test and z-test results show that the values for the multiple directorships, political connection, firm size, and firm growth are more than the significance level of 0.05 . These independent variables do not significantly affect ROA, while leverage has significant negative affects the ROA in FEM and REM models. Thus, $\mathrm{H} 1$ and $\mathrm{H} 2$ are not proven with both FEM and REM models, and we continue to use the PLS model.

Table 10. Fixed Effect (FEM) and Random Effect (REM) Regression Analysis Result - ROE

\begin{tabular}{lcccccc}
\hline \multirow{2}{*}{$\begin{array}{l}\text { Independent } \\
\text { Variable }\end{array}$} & \multicolumn{3}{c}{ FEM } & \multicolumn{3}{c}{ REM } \\
\cline { 2 - 7 } & $\boldsymbol{\beta}$ & $\mathbf{t}$-count & Sig. $\mathbf{t}$ & $\boldsymbol{\beta}$ & Z-count & Sig. Z \\
\hline $\begin{array}{l}\text { Multiple } \\
\text { Directorship }\end{array}$ & 0.1138065 & 0.04 & 0.969 & -1.867367 & -2.72 & 0.056 \\
Political & & & & & & \\
Connection & 0.0873298 & 0.03 & 0.975 & 0.8019719 & 2.03 & 0.132 \\
Firm Growth & 0.0037442 & 0.14 & 0.891 & 0.0066426 & 1.49 & 0.787 \\
Firm Size & $-1.58 \mathrm{e}-08$ & -5.33 & 0.000 & $-1.33 \mathrm{e}-08$ & -3.4 & 0.000 \\
Leverage & 0.5159589 & 26.25 & 0.000 & 0.5097319 & 3.74 & 0.000 \\
Constant & -0.1586732 & -0.06 & 0.948 & 1.206647 & 2.16 & 0.193 \\
\hline & R-squared & 0.7557 & & R-squared & 0.7656 & \\
& F-count & 140.13 & & F-count & 824.68 & \\
& Sig F & 0.0000 & & Sig X2 & 0.0000 & \\
\hline
\end{tabular}

Source: Data processed by researchers using Stata, 2021

Based on Table 10, the F test with the FEM model and $\chi 2$ test with the REM model resulted in a probability of 0.0000 and 0.0000 with a significance level of 0.05 . Thus, both models that use the control variable are fit to predict the firm performance as proxied by ROE. Furthermore, the t-test and z-test results show that the values for multiple boards, political connection, and firm growth are more than the significance level of 0.05. These independent variables do not significantly affect ROE. Meanwhile, leverage has a significant positive relationship, and firm size has a significant negative relationship with ROE in FEM and REM models. Thus, $\mathrm{H} 1$ and $\mathrm{H} 2$ are not proven with both FEM and REM models, and we continue to use the PLS model.

Table 11. Two-Stage Least Square Regression Analysis Result

\begin{tabular}{lrrrrrr}
\hline \multirow{2}{*}{$\begin{array}{l}\text { Independent } \\
\text { Variable }\end{array}$} & \multicolumn{2}{c}{ Equation Model 1 (ROA) } & \multicolumn{2}{c}{ Equation Model 2 (ROE) } \\
\cline { 2 - 7 } & \multicolumn{1}{c}{$\boldsymbol{\beta}$} & $\mathbf{t}$-count & Sig. t & \multicolumn{1}{c}{$\boldsymbol{\beta}$} & t-count & Sig. t \\
\hline Multiple & & & & & & \\
Directorship & -12.73219 & -0.12 & 0.908 & -3.30321 & -2.09 & 0.037 \\
Political & & & & & & \\
Connection & 9.12032 & 1.77 & 0.079 & 0.5023812 & 1.68 & 0.093 \\
Firm Growth & 0.192347 & 0.05 & 0.322 & 0.0109523 & 0.32 & 0.753 \\
Firm Size & $23 . \mathrm{e}-12$ & 1.61 & 0.470 & $-3.91 \mathrm{e}-08$ & -5.65 & 0.001 \\
Leverage & -2.102939 & -2.47 & 0.001 & 0.3912021 & 28.37 & 0.001 \\
Residuals & 8.219202 & 1.14 & 0256 & 0.1237 & 2.34 & 0,184 \\
Constant & 2.573021 & 0.30 & 0.186 & 1.20334 & 1.42 & 0.157 \\
\hline & R-squared & 0.5798 & & R-squared & 0.7610 & \\
& F-count & 15.70 & & F-count & 25.72 & \\
& Sig F & 0.0000 & & Sig F & 0.0001 & \\
\hline
\end{tabular}

Source: Data processed by researchers using Stata, 2021 
Wintoki et al. (2012) reported that most corporate governance variables are endogenous. Moreover, Ordinary least squares (OLS), fixed effect (FE), and random effect (RE) generally ignore the endogeneity in the model. They are considered biased and inconsistent by ignoring endogeneity (Vo \& Nguyen, 2014). Therefore, we establish a twostage least square (2SLS) regression analysis to test whether the chosen research's model has an endogenous effect (Bollmann et al., 2019). In the first stage, we use multiple directorship variables as dependent variables, then proceed with the regression analysis with all independent variables and then calculate the residual. Therefore, we use the dependent variable from the firm performance and proceed with the regression analysis with all of the study's independent variables and include the previously calculated residuals. Based on table 11, the residual in the two research equation models with PLS are more than the significance level of 0.05 . The residuals do not significantly explain the two dependent variables for measuring the firm performance in aviation companies. Thus, the endogeneity problem does not occur in the two research equation models.

\section{DISCUSSION}

Based on the results of panel-data regression as presented in Table 8, H1 is accepted with a probability value of 0.043 and the $t$ value of 2.03 . Thus, the results confirm that the board members' political connection in aviation companies in Asia significantly influences the aviation companies' performance. The result of this study is in line with the previous research's results from Brown (2016), (Wong \& Hooy, 2018), and Arifin et al. (2020), which state that political connection has a positive effect on firm performance. The result of the research also supports the study done by (Brogaard et al., 2021). The solid political connection in aviation companies can reduce the negative effect of economic turbulence and business uncertainty, especially during Covid-19. There is also a high likelihood that these solid political powers can make companies gain the upper hand on the more straightforward implementation and compliance with laws and regulations for aviation companies with strict regulation.

Therefore, appointing board members with solid political connections could reflect shareholder's right decisions. However, the shareholders still need to be careful in appointing board members. The shareholders should also consider other aspects outside extensive experiences, such as the board candidate's Key Performance Indicator (KPI) from the previous companies. In addition, the shareholder could consider other requirements, such as risk management skills and crisis leadership characteristic set, to manage the lower firm performance because of crisis. Additionally, to enhance the political connection of board members, the shareholders could also encourage the existing board members to improve the firm's effectiveness rather than appointing new members. During the pandemic crisis, the board members should put more emphasis on monitoring the liquidity level. Moreover, they should also monitor the realization of sales targets rather than increase the target and then consider setting new targets sensitive to the current situation.

For the multiple directorships, table 8 shows that $\mathrm{H} 2$ is rejected. The result is proved by the probability value of 0.007 and the $t$ value of -2.72 . The result is not in line with the previous research's results from Hundal (2017), Manna et al. (2020), and (Chee \& Tham, 2021), which state that multiple directorships have a positive effect on firm performance. However, the results support the previous research's results from Harymawan et al. (2019) and Ooi (2020). The researchers stated that the multiple directorships that 
emphasize director's business harm firm performance in the different business sectors outside aviation companies. Based on the year observed, the study results showed that having multiple directorships could decrease firm performance, especially during uncertainties like Covid-19 Pandemic. Therefore, the shareholder should be aware of board members' busyness risks. In addition, the shareholder should be conscious that the negative effect is more significant in high-growth firms with short tenure of managing directors than firms with a long tenure of managing directors (Harymawan et al., 2019). The company's shareholders could manage the risk by monitoring the attendance list for required board meetings and set the KPI required activities and firm performance.

For the control variables, table 8 shows that leverage has a significant positive relationship and firm size has a significant negative relationship with ROE. The result is proved by the leverage variable having the probability value of 0.000 and the $t$ value of 3.74. The firm size variable has a probability value of 0.001 and the $t$ value of -3.4 . In addition, table 7 also shows that firm size has a significant negative effect on ROA. The result is provided by the firm size variable having the probability value of 0.040 and the $t$ value of 2.06. The leverage' effect is not in line with the previous research's results from Terjesen et al. (2016). Firms that have a considerable proportion of debt have a negative relationship with their firm performance. However, the results support the previous research's results from Ibhagui et al. (2018) and Seissian et al. (2018). The researchers stated that leverage has a positive and significant effect on a firm's profitability. In addition, the result of the firm size' effect is also not in line with other research's results from Aydin Unal et al. (2017), where the large companies have better firm performance in terms of profitability ratio than small companies. However, the results support the research from Subramaniam \& Wasiuzzaman (2019), where the firm size significantly influences ROA. Therefore, the shareholder should also consider the size of the firms where the large companies usually appoint the board members from the same company group in inter-firm relationships (Mazzola et al., 2016). Moreover, the board members should effectively utilize the debt, especially during economic uncertainties.

Overall, the results show that the multiple directorships negatively affect firm performance in aviation companies measured by its Return on Equity (ROE). However, the results also show that the board's political connections positively impact firm performance measured by its Return on Equity (ROE). In contrast, the multiple directorships and political connections do not impact firm performance in aviation companies measured by their Return on Assets (ROA). For the control variables, the leverage has a significant positive relationship with $\mathrm{ROE}$, and firm size has a significant negative relationship with ROA and ROE.

\section{CONCLUSION, LIMITATIONS, AND SUGGESTIONS}

Based on the research's result, the researcher concludes that the political connection of the board of commissioners in aviation companies positively impacts the firm performance's aviation companies. In addition, the average proportion for board members having political is $51 \%$ from total board members. Having half board of commissioner has the former experience as government officials enhance the board's political connection. Thus, the shareholders of aviation companies consider appointing board members as a government endorsement and support signal, especially during economic uncertainties. Furthermore, as opposed to the previous result, the research 
suggests that board members serve in multiple boards harms the firm's performance in aviation companies. However, the average proportion for board members who also serve in other companies is more than the proportion of board members having political connections, $88 \%$ of total board members. The multiple directorships relate to the director's busyness where they cannot adequately monitor the company, which the situations are likely more intense than usual. Therefore, the shareholder should consider the busyness risks in appointing the board of directors' members as commissioners in other companies. The shareholders also should monitor the attendance list for required board meetings. For the control variables, the leverage has a significant positive relationship with ROE and firm size has a significant negative relationship with ROA and ROE. Thus, the shareholder should also consider the size of the firms where the large companies usually appoint the board members from the same company group in interfirm relationships.

Following the conclusion, this research has limitations that can be further developed by subsequent researchers interested in researching this topic. First, researchers can set more indicators related to political connection variables, such as the experience of being a former party member or being a successful team for incumbent government officials. Second, aspiring researchers can also set more indicators on firm performance variables such as Tobin's $Q$ or price per earnings ratio. Finally, they can also add more than five years to see the broader impact of the two dependent variables.

Third, the following researchers can develop research using samples from aviation companies located on different continents but have a reasonably similar governance system such as America and Europe. By examining these companies, researchers can compare the results of their research with research on the Asian continent. Therefore, limitations in research can affect the study results, so these limitations should be evaluated through academic references. In the end, research related to governance in the scope of the board of directors and commissioners in aviation companies requires development in further research

\section{REFERENCES}

Adetunji, O. M., \& Owolabi, A. A. (2016). Firm Performance and Its Drivers: How Important Are the Industry and Firm-Level Factors? International Journal of Economics and Finance, 8(11), 60. https://doi.org/10.5539/ijef.v8n11p60

Air Transport Action Group. (2021). Facts and Figures. https://www.atag.org/component/factfigures/?Itemid=

Alejo, J., Montes-Rojas, G., \& Sosa-Escudero, W. (2015). Tests for Normality in Linear Panel Data Models. Stata Journal, 15(3), 822-832. http://www.statajournal.com/software/sj15-3/st0406/

Arifin, T., Hasan, I., \& Kabir, R. (2020). Transactional and relational approaches to political connections and the cost of debt. Journal of Corporate Finance, 65, 101768. https:// doi.org/10.1016/j.jcorpfin.2020.101768

Aydın Unal, E., Unal, Y., \& Isık, O. (2017). The Effect of Firm Size on Profitability: Evidence From Turkish Manufacturing Sector. Pressacademia, 6(4), 301-308. https:// doi.org/10.17261/pressacademia.2017.762 
Bollmann, G., Rouzinov, S., Berchtold, A., \& Rossier, J. (2019). Illustrating Instrumental Variable Regressions Using the Career Adaptability - Job Satisfaction Relationship. Frontiers in Psychology, 10, 1481. https:/ / doi.org/10.3389/fpsyg.2019.01481

Brogaard, J., Denes, M., \& Duchin, R. (2021). Political Influence and the Renegotiation of Government Contracts. The Review of Financial Studies, 34(6), 3095-3137. https://doi.org/10.1093/rfs/hhaa093

Brogaard, J., \& Detzel, A. (2015). The Asset-Pricing Implications of Government Economic Policy Uncertainty. Management Science, 61(1), 3-18. https:/ / econpapers.repec.org/RePEc:inm:ormnsc:v:61:y:2015:i:1:p:3-18

Brown, R. S. (2016). Management Lobbying, political connectedness and financial performance in the air transportation industry. Journal of Air Transport Management, 54, 61-69. https:/ / doi.org/10.1016/j.jairtraman.2016.03.009

Chee, K. D., \& Tham, Y. H. (2021). The role of directors with multiple board seats and earnings quality: A Singapore context. Journal of Corporate Accounting $\mathcal{E}$ Finance, 32(1), 31-47. https://doi.org/10.1002/jcaf.22474

Daoud, J. I. (2017). Multicollinearity and Regression Analysis. Journal of Physics: Conference Series, 949, 12009. https:/ / doi.org/10.1088/1742-6596/949/1/012009

Eloff, J. J., \& Cohen, J. P. (2015). Airport Infrastructure Investment: Strategic Interaction or Strategic Allocation? Transportation Research Record, 2471(1), 26-32. https:// doi.org/10.3141/2471-04

Harymawan, I., Nasih, M., Ratri, M. C., \& Nowland, J. (2019). CEO busyness and firm performance: evidence from Indonesia. Heliyon, 5(5), e01601-e01601. https:// doi.org/10.1016/j.heliyon.2019.e01601

Hundal, S. (2017). Multiple directorships of corporate boards and firm performance in India. Corporate Ownership and Control, 14, 150-164. https:// doi.org/10.22495/cocv14i4art13

Ibhagui, O. W., \& Olokoyo, F. O. (2018). Leverage and firm performance: New evidence on the role of firm size. The North American Journal of Economics and Finance, 45, 5782. https://doi.org/https://doi.org/10.1016/j.najef.2018.02.002

Ibhagui, O. W., Olokoyo, F. O., Lee, S., Vithessonthi, C., \& Tongurai, J. (2018). The effect of firm size on the leverage-performance relationship during the financial crisis of 2007-2009. Journal of Multinational Financial Management, 29(1), 607-625. https:// doi.org/https://doi.org/10.1016/j.najef.2018.02.002

King Committee on Corporate Governance. (2016). KIng IV Report on Corporate Governance for South Africa. https://cdn.ymaws.com/www.iodsa.co.za/resource/collection/684B68A7-B768465C-8214-E3A007F15A5A/IoDSA_King_IV_Report_-_WebVersion.pdf

Lee, S. (2018). Growth, profits and R\&D investment. Economic Research-Ekonomska Istraživanja, 31(1), 607-625. https:/ / doi.org/10.1080/1331677X.2018.1432380

Manna, A., Sahu, T. N., \& Pandey, K. D. (2020). Board size, multiple directorship and performance of Indian listed firms. International Journal of Economics and Business 
Research,

19(2),

111-129.

https:// econpapers.repec.org/RePEc:ids:ijecbr:v:19:y:2020:i:2:p:111-129

Mazzola, E., Perrone, G., \& Kamuriwo, D. S. (2016). The interaction between inter-firm and interlocking directorate networks on firm's new product development outcomes. Journal of Business Research, 69(2), 672-682. https:// doi.org/10.1016/j.jbusres.2015.08.033

Mckinsey \& Company. (2020). Covid-19: Global Health and Crisis Response.

Morrisan, M. A. (2019). Metode Penelitian Survei. Kencana. https:// books.google.co.id/books?id=LhZNDwAAQBAJ

Moscone, F., \& Tosetti, E. (2015). Robust estimation under error cross section dependence. Economics Letters, 133, 100-104. https:// doi.org/https:// doi.org/10.1016/j.econlet.2015.05.020

Ooi, E. (2020). Directors who serve multiple pension funds: Are they conflicted or skilled? Journal of Banking and Finance, 113, 105764. https:// doi.org/10.1016/j.jbankfin.2020.105764

Pek, J., Wong, O., \& Wong, A. C. M. (2018). How to Address Non-normality: A Taxonomy of Approaches, Reviewed, and Illustrated. Frontiers in Psychology, 9, 2104. https:// doi.org/10.3389/fpsyg.2018.02104

Pesaran, M. H. (2015). Time Series and Panel Data Econometrics. Oxford University Press. https:// books.google.co.id/ books?id=5jITDAAAQBAJ

Pillai N., V. (2016). Panel Data Analysis with Stata Part 1 Fixed Effects and Random Effects Models. https://mpra.ub.uni-muenchen.de/76869/1/MPRA_paper_76869.pdf

Preuss, S., \& Königsgruber, R. (2021). How do corporate political connections influence financial reporting? A synthesis of the literature. Journal of Accounting and Public Policy, 40(1), 106802. https:// doi.org/10.1016/j.jaccpubpol.2020.106802

Rizka, Z. (2019). Estimation Model And Selection Method Of Panel Data Regression: An Overview Of Common Effect, Fixed Effect, And Random Effect Model. https:/ / osf.io/9qe2b/download/?format=pdf

Rosana, F. C. (2020). Erick Thohir Stated His Reason In Appointing Triawan Munaf as Garuda's President Commissioner. Tempo. https:/ / bisnis.tempo.co/read/1298702/erick-thohir-sebut-alasan-pilih-triawanmunaf-jadi-komut-garuda

Saleh, M. W. A., Shurafa, R., Shukeri, S. N., Nour, A. I., \& Maigosh, Z. S. (2020). The effect of board multiple directorships and CEO characteristics on firm performance: evidence from Palestine. Journal of Accounting in Emerging Economies, 10(4), 637-654. https:// doi.org/10.1108/JAEE-12-2019-0231

Seissian, L. A., Gharios, R. T., \& Awad, A. B. (2018). Structural and market-related factors impacting profitability: A cross sectional study of listed companies. Arab Economic and Business Journal, 13(2), 125-133. https:// doi.org/https://doi.org/10.1016/j.aebj.2018.09.001 
Subramaniam, V., \& Wasiuzzaman, S. (2019). Geographical diversification, firm size and profitability in Malaysia: A quantile regression approach. Heliyon, 5(10), e02664. https://doi.org/https://doi.org/10.1016/j.heliyon.2019.e02664

Tangel, A. (2019). Boeing Strips CEO Of Chairman's Job. The Wallstreet Journal. https:// www.wsj.com/articles/boeing-strips-ceo-of-chairmans-job-11570833244

Taouab, O., \& Issor, Z. (2019). Firm Performance: Definition and Measurement Models. European Scientific Journal ESJ, 15(1), 93-106. https:// doi.org/10.19044/esj.2019.v15n1p93

Terjesen, S., Couto, E. B., \& Francisco, P. M. (2016). Does the presence of independent and female directors impact firm performance? A multi-country study of board diversity. Journal of Management $\mathcal{E}$ Governance, 20(3), 447-483. https:// doi.org/10.1007/s10997-014-9307-8

The Chartered Governance Institute. (2020). What is corporate governance? https://www.cgi.org.uk/about-us/policy/what-is-corporate-governance

Veazie, P. J. (2015). Understanding Statistical Testing. SAGE Open, 5(1), 2158244014567685. https:// doi.org/10.1177/2158244014567685

Vithessonthi, C., \& Tongurai, J. (2015). The effect of firm size on the leverage-performance relationship during the financial crisis of 2007-2009. Journal of Multinational Financial Management, 29 , $1-29$. https:// doi.org/https://doi.org/10.1016/j.mulfin.2014.11.001

Vo, D., \& Nguyen, T. (2014). The Impact of Corporate Governance on Firm Performance: Empirical Study in Vietnam. International Journal of Economics and Finance, 6. https:// doi.org/10.5539/ijef.v6n6p1

Wang, Y., Yao, C., \& Kang, D. (2018). Political connections and firm performance: Evidence from government officials' site visits. Pacific-Basin Finance Journal, 57. https:// doi.org/10.1016/j.pacfin.2018.05.003

Wardana, S. (2019). Erick Thohir "surprised" that an SOE director served in six other commissioner seats at once. The Jakarta Post. https://www.thejakartapost.com/news/2019/12/14/erick-thohir-surprised-thatan-soe-director-served-in-six-other-commissioner-seats-at-once.html

Wati, L. N. (2017). Board of commissioner's effectiveness on politically connected conglomerates: Evidence from Indonesia. Pertanika Journal Social Sciences $\mathcal{E}$ Humanities, 25, 255-270.

Wintoki, M. B., Linck, J. S., \& Netter, J. M. (2012). Endogeneity and the dynamics of internal corporate governance. Journal of Financial Economics, 105(3), 581-606. https:// doi.org/10.1016/j.jfineco.2012.03.005

Wong, W.-Y., \& Hooy, C.-W. (2018). Do types of political connection affect firm performance differently? Pacific-Basin Finance Journal, 51, 297-317. https:// doi.org/https://doi.org/10.1016/j.pacfin.2018.08.009 